\title{
Relationship between lower urinary tract symptoms and prostatic anatomic characteristics in patients with obesity and severe obesity
}

\author{
Relación entre los síntomas del tracto urinario bajo y las características anatómicas de la \\ próstata en pacientes con obesidad y obesidad grave
}

\author{
Aarón Flores-Aguilar', José A. Olivo-Gárate1 , Álvaro Montiel-Jarquín ${ }^{1 *}$, Marco A. Chopin-Gazga1, \\ Margarita Serrano-Mendoza ${ }^{1}$, and Ana L. Pérez-Vázquez ${ }^{1,2}$ \\ ${ }^{1}$ Directorate of Education and Research in Health, Hospital de Especialidades Puebla, Puebla, Instituto Mexicano del Seguro Social (IMSS), Puebla; \\ ${ }^{2}$ Department of Health Research, Monterrey Institute of Technology and Higher Education, Monterrey, Nuevo León. México
}

\begin{abstract}
Objective: The objective of the study was to compare lower urinary tract symptoms and prostatic anatomic characteristic with prostatic enlargement in obese patients. Materials and methods: A comparative and cross-sectional study was conducted from October 2018 to November 2018. Lower urinary tract symptoms were compared in patients with body mass index (BMI) 30-34.9 and BMI 35-39. To evaluate these symptoms, the International Prostatic Symptom Score (IPSS) was used on 537 patients. The variables were age, weight and size, BMI, prostatic volume measurement by ultrasound, prostate-specific antigen (PSA), and finasteride treatment. Descriptive statistic was used, Cronbach's alpha, Fisher's exact test, and Chi-square. Results: One hundred fulfilled inclusion criteria. Mean values were age 68.73 years, weight $84.98 \mathrm{~kg}$, size 1.61 m, BMI 32.62 , ultrasonographic prostatic size was $69.09 \mathrm{~cm}^{3}$, and PSA $1.94 \mathrm{ng} / \mathrm{dl}$. The IPSS was severe in 3.6\% (Group 1), 17.6\% (Group 2); moderate $72 \%$ (Group 1), 70.5\% (Group 2); and mild 33.3\% (Group 1), 11.7\% (Group 2), with significant differences between both groups $(p=0.05)$. Differences between values of prostatic volume and BMI did not show statistical significance $(p \geq 0.05)$. Conclusion: Statistical association between obesity and severe obesity and lower urinary tract symptoms is positive.
\end{abstract}

Key words: Benign prostatic hyperplasia. Obesity. Urinary symptoms.

\section{Resumen}

Objetivo: Comparar los síntomas del tracto urinario bajo y las características anatómicas de la próstata en pacientes con crecimiento prostático y obesidad. Método: Estudio comparativo, transversal, realizado de octubre a noviembre de 2018. Se compararon los síntomas del tracto urinario bajo y las características anatómicas de la próstata presentados por pacientes con obesidad y obesidad grave. Se aplicó el Índice Específico de Síntomas Prostáticos (IPSS) para evaluar los síntomas del tracto urinario bajo. Variables: edad, peso, talla, índice de masa corporal (IMC), volumen prostático por ultrasonido, antígeno prostático específico (PSA) y finasterida. Estadística: descriptiva, alfa de Cronbach, pruebas exacta de Fisher y ji al cuadrado. Resultados: De 537 pacientes, 100 cumplieron los criterios de inclusión. Edad media: 68.73 años; peso medio: $84.98 \mathrm{~kg}$; talla media: $1.61 \mathrm{~m}$; IMC medio: 32.62 ; tamaño prostático ultrasonográfico medio: $69.09 \mathrm{~cm}^{3}$; cuantificación media de PSA: $1.94 \mathrm{ng} / \mathrm{dl}$. El 72\% tuvieron un IPSS moderado en ambos

\section{Correspondence:}

*Álvaro J. Montiel-Jarquín

Norte, 2004

Col. Centro

Date of reception: 03-04-2019

C.P. 72000 , Puebla, Pue., México

E-mail: alvaro.montielj@imss.gob.mx

0009-7411/@ 2020 Academia Mexicana de Cirugía. Published by Permanyer. This is an open access article under the terms of the CC BY-NC-ND license (http://creativecommons.org/licenses/by-nc-nd/4.0/). 
grupos. La diferencia entre IMC y síntomas del tracto urinario bajo tuvo una $p=0.05$; no así el volumen prostático y el IMC en ambos grupos ( $p>0.05)$. Conclusión: Existe asociación entre la obesidad y la obesidad grave con los síntomas del tracto urinario bajo.

Palabras clave: Hiperplasia benigna de próstata. Obesidad. Síntomas urinarios.

\section{Introduction}

Excess of body weight (overweight and obesity) is currently acknowledged as one of the most important challenges worldwide in public health. This is due to its magnitude, the rapid increase and negative repercussions on the affected population's health. Mexico is a country with a rising trend in diseases associated with poor nutrition and their comorbidities'.

Benign prostatic hyperplasia (BPH) is a urologic disease with a high prevalence in males older than 60 years old ${ }^{2}$. The prevalence is greater in white and Afro-American males; however, it tends to be more severe and progressive in Afro-Americans, possibly due to higher testosterone levels, $>$ 5-alpha reductase activity, androgen receptor expression, and growth factor activity in this population ${ }^{3}$. Although multiple inflammatory, hormonal, and environmental factors and lifestyle can predispose to this condition, they have yet to be completely defined ${ }^{4}$.

Furthermore, there is enough evidence that suggests obesity as stimulating factor of $\mathrm{BPH}^{5}$. Different studies reveal that the increase of adipocytes, determined by anthropometric measurements, is positively associated with prostatic volume ${ }^{5}$. The greater quantity of adipose tissue, the more prostatic volume. Therefore, obesity is directly associated with prostatic enlargement. A recent analysis of more than 16,000 specimens of radical prostatectomy has validated these findings and reveals the association that for each $\mathrm{kg} / \mathrm{m}^{2}$, there is an increase of $0.45 \mathrm{~g}$ in the total of prostatic weight 5 .

In Mexico, it is poorly known the association between $\mathrm{BPH}$ and obesity. Recently, it has been suggested that an individual with obesity can be risk factor for BPH and lower urinary tract symptoms. Despite the existence of multiple studies international wise, research has not been done at national level about the correlation between body mass index (BMI) and prostatic volume with the severity of lower urinary tract symptoms. The aim of this study was to define the relation between the lower urinary tract symptoms and prostatic anatomic characteristics in patients with obesity and severe obesity.

\section{Materials and methods}

A comparative, cross-sectional study was conducted from October 2018 to November 2018. The population included was male patients between 60 and 80 years old with lower urinary tract symptoms and prostatic volume $>30 \mathrm{~g}$, measured by suprapubic ultrasound, that were willing to participate and signed informed consent. Exclusion criteria were prostatic specific antigen (PSA) equal or $>4 \mathrm{ng} / \mathrm{dl}$. The anthropometric evaluation was performed to measure weight and height. Weight balance and telescopic height measuring rod were used and measures were expressed in centimeters and grams. The WHO criteria were employed to determine overweight and obesity.

Patients included in this study were divided into two groups according to the BMI (obesity and severe obesity), Group 1 had a BMI $\leq 34.9$ and Group 2 had a BMI of 35-39.9.

To evaluate these symptoms, the International Prostatic Symptoms Score (IPSS) was used. A score of 0-7 indicates mild symptoms, 8-19 indicates moderate symptoms, and 20-35 indicates severe symptoms.

The variables were age, weight, and size, BMI, prostatic volume measured by ultrasound, PSA, IPSS, and finasteride treatment. Descriptive statistic on IBM program SPSS v25 for Mac was used, as well as frequency, percentages, central tendency measures, and dispersion, Fisher's exact test, and Chi-square.

The sampling was deterministic, given by the total of patients that fulfilled inclusion criteria in the time frame of the study.

The research protocol was duly authorized by the local ethics and research committee of the participating medical unit under the registration R-2018-2101062. Confidentiality of the patients was maintained at all times.

\section{Results}

Five hundred and thirty-seven patients were surveyed, only 100 patients fulfilled inclusion criteria, which delivers a sample prevalence of 1.862 . Mean 
Table 1. Internal consistency of IPSS applied to patients

\begin{tabular}{llc}
\hline & Symptom & Chronbach's alpha \\
\hline Urine storage & $\begin{array}{l}\text { Incomplete emptying } \\
\text { Intermittency }\end{array}$ & 0.272 \\
& Urgency & \\
Voiding & Straining & \\
& Nocturia & 0.601 \\
& Weak stream & \\
& Frequency & \\
Total score 0.748 & &
\end{tabular}

IPSS: International Prostate Symptom Score.

values were age 68.73 , standard deviation (SD) 5.44 years; weight 84.98, SD $7.11 \mathrm{~kg}$; size 1.61, SD $0.05 \mathrm{~m}$; and BMI 32.62, SD 2.17 and $36(36 \%)$ were on finasteride treatment on therapeutic doses. Mean ultrasonographic prostatic size was 69.09 , SD $33.93 \mathrm{~cm}^{3}$ and quantification of PSA 1.94, SD $1.07 \mathrm{ng} / \mathrm{dl}$.

Cronbach's alpha for internal consistency of IPSS delivered 0.272 for urine storage, 0.601 for urine voiding, and a total punctuation of 0.748 (Table 1).

Regarding the relation between the grade of prostatic enlargement and medical treatment, 36 patients were administered finasteride and 64 were not; no significant statistical differences were found $(p=0.17)$, details are shown in table 2. In addition, differences between BMI and ultrasonographic prostatic measurements in both groups delivered a value of $p=0.92$ (Table 3).

Mean values for Group 1 and Group 2 were as follows: age 68.1 and 71.6 years old, weight 83.8 and 91.5, and BMI 31.9 and 36.3, ultrasound prostatic volume $\left(\mathrm{cm}^{3}\right)$ measured by ultrasound 69.3 and 68.95 , PSA 1.88 and 2.2, IPSS 4.588 and 5.63.

There were 22 patients with mild IPSS, from these 20 had obesity and 2 severe obesity; 72 with moderate IPSS, from these 60 had obesity and 12 severe obesity; and 6 with severe IPSS, from these 3 had obesity and 3 severe obesity. There were significant statistical differences between the groups $(p=0.05)$.

On the other side, from the 83 patients with obesity, 31 had prostatic hyperplasia Grade II, 29 Grade III, and 23 Grade IV; from the 17 patients with severe obesity, 6 had prostatic hyperplasia Grade II, 6 Grade III, and 5 Grade IV. The association between these two grades of obesity and the grade of BPH measured by ultrasound did not report statistically significant differences, $\mathrm{p}=0.985$.

\section{Discussion}

The global epidemic of obesity and its strong relation with multiple urologic diseases have turned it into a critical issue.

In this study, where 537 patients were surveyed, 100 fulfilled inclusion criteria, which deliver a sample prevalence of 1.862 in the studied time frame. Mean age and mean BMI of all surveyed patients were 68.73 and 32.65 , respectively. These data are similar to the reported by other authors regarding the patient's age. Gacci et al. reported 69.7 years $^{6}$, De Nuzio et al. 68.8 years ${ }^{2}$, and Antunez et al. 66 years $^{7}$. Nevertheless, it is not equivalent to the BMI of other studies such as Bhindi et al. trial with a mean of $27.1^{8}$, Jung et al. 25.679, Yin et al. $27.3^{10}$, and Fowke et al. $28.5^{11}$. As for the use of previous medication to the study, only $36 \%$ were on finasteride treatment; $38 \%$ of them had Grade II prostatic enlargement, 36\% Grade III, 26\% Grade IV, and a mean PSA level of $1.94 \mathrm{ng} / \mathrm{dl}$.

In respect of this study, among the patients with finasteride treatment, 25\% had Grade II enlargement, $44.4 \%$ Grade III, and $30.55 \%$ Grade IV. In contrast, there was a greater percentage of patients in the different prostatic enlargement grades in patients with no medical treatment. This is controversial since in medical literature, it is described a total improvement of prostatic enlargement with finasteride. We considered that this could be due to the lack of inquiry about adherence to treatment. Nevertheless, significant statistical difference was not established between both groups $(p=0.17)$. Bhindi et al. mentioned that there is no relation between BMI and IPSS with finasteride treatment ${ }^{8}$.

In addition, the ultrasonographic characteristics of prostate provided a mean prostatic volume of $69.31 \mathrm{~g}$ in patients with Class I obesity and $69.95 \mathrm{~g}$ in patients with Class II. There were not significant statistical differences between both groups, $p \geq 0.05$. In comparison, Bhindi et al. ${ }^{8}$ reported a mean prostatic volume of $52 \mathrm{~g}$, Fowke et al. ${ }^{11} 48 \mathrm{~g}$, and Antunez et al. $36.8 \mathrm{~g}^{7}$. In Mexico, there have been no studies that establish a correlation between obesity and prostatic enlargement, therefore, there is no point of reference ${ }^{12}$.

Regarding PSA values of this study (1.94 $\mathrm{ng} / \mathrm{dl})$, this concurs with the reported values by Gacci et al. ${ }^{6}$ that mentioned a mean value of $2.6 \mathrm{ng} / \mathrm{dl}$. However, other authors report greater mean PSA values, for example, Bhindi et al. reported PSA of $5.02 \mathrm{ng} / \mathrm{dl}$, Jung et al. $3.19 \mathrm{ng} / \mathrm{dl}$, De Nunzio et al. $3.2 \mathrm{ng} / \mathrm{dl}$, and Fowke et al. $4.5 \mathrm{ng} / \mathrm{d}^{8,9,2,11}$. Differences between mean PSA values 
Table 2. Prostatic enlargement grading and finasteride treatment

\begin{tabular}{|c|c|c|c|c|c|c|c|}
\hline & \multicolumn{3}{|c|}{ Finasteride treatment } & \multirow[t]{2}{*}{$\chi^{2}$} & \multirow[t]{2}{*}{$p$} & \multirow[t]{2}{*}{$\mathrm{Cl} 95$} & \multirow[t]{2}{*}{$\%$} \\
\hline & With finasteride & No finasteride & Total & & & & \\
\hline Prostatic enlargement grading & & & & 3.75 & 0.17 & 0.96 & 0.24 \\
\hline II & 9 & 28 & 37 & & & & \\
\hline III & 16 & 19 & 35 & & & & \\
\hline IV & 11 & 17 & 28 & & & & \\
\hline Total & 36 & 64 & 100 & & & & \\
\hline
\end{tabular}

Table 3. Differences between prostatic measurement by ultrasound in both groups of patients

\begin{tabular}{lcccc}
\hline \multicolumn{5}{c}{ Prostatic measurement by ultrasound } \\
\hline & Mean & $\mathbf{\pm}$ & $\mathbf{U}$ & $\mathbf{p}$ \\
\hline Group 1 & 69.31 & 35.05 & & \\
Group 2 & 68.95 & 30.05 & 695.5 & 0.92 \\
\hline p: probability; U: U-statistic. \pm : standard deviation. & &
\end{tabular}

in this study and the previous mentioned lie in the exclusion of patients with PSA levels $>4 \mathrm{ng} / \mathrm{dl}$ due to the increased risk of prostate cancer.

The internal consistency of the IPSS was low for both storage and voiding symptoms with a Cronbach's alpha of 0.272 and 0.601 , respectively. However, the internal consistency of the total value of IPSS (7 categories) was 0.748 , which is considered acceptable. De Nunzio et al., in 2014, with a population of 431 patients, found an obesity prevalence of $26 \%$, this is greater than the one in our study (18\%) with similar findings regarding IPSS values and prostatic volume ${ }^{2}$.

The findings in IPSS in this study were as follows: $21 \%$ of patients with mild symptoms, $73 \%$ with moderate symptoms, and $6 \%$ severe. Gacci et al. ${ }^{6}$ had $14.3 \%$ of patients with mild IPSS, $55.7 \%$ moderate, and $30 \%$ severe. These results differ due to the percentage of patients included in the group with Grade III prostatic enlargement which presents more symptoms than Group II.

The patients with Class II obesity had a greater symptomatology of the lower urinary tract than patients with Class I obesity, 11.10 and 13.41 , respectively. There is a significant statistical association, $p=0.05$. This also coincides with global medical literature, where it is reported that the greater the BMI is, the greater lower urinary tract symptoms is ${ }^{13}$.

Vignozzi et al. in 2016 reported multiple prospective studies with the objective to determine a positive association between BMI and lower urinary tract symptoms. However, despite the positive result for this association (the greater the BMI, the greater lower urinary tract symptoms) in the prostate center prevention trial; in osteoporotic fractures in Men Study and Southern Community Cohort Study, there are two prospective studies that deny said association ${ }^{14}$.

Finally, there was no significant statistical association between BMI and prostatic measurement by ultrasound, $p=0.985$.

Although some studies conclude that moderate to vigorous physical activity is associated to $\mathrm{BPH}$ and lower urinary tract symptoms, this study did not consider physical activity as a variable, therefore, it was not possible to establish an association to physical activity ${ }^{15}$.

A limitation of this study is the size of the sample. A larger $\mathrm{N}$ is needed to demonstrate the hypothesis.

We propose to carry out a greater follow-up of the patients to determine the changes found in these results.

\section{Conclusion}

There is an association between obesity, severe obesity, and lower urinary tract symptoms presented in the patients.

\section{Conflicts of interest}

The authors declare have no they any conflicts of interest.

\section{Ethical disclosures}

Protection of human and animal subjects. The authors declare that no experiments were performed on humans or animals for this study.

Confidentiality of data. The authors declare that they have followed the protocols of their work center on the publication of patient data. 
Right to privacy and informed consent. The authors have obtained the written informed consent of the patients or subjects mentioned in the article. The corresponding author is in possession of this document.

\section{References}

1. Dávila-Torres J, González-Izquierdo JJ, Barrera-Cruz A. Panorama de la obesidad en México. Rev Med Inst Mex Seguro Soc. 2015;53:240-9.

2. De Nunzio C, Cindolo L, Gacci M, Pellegrini F, Carini M, Lombardo R et al. Metabolic syndrome and lower urinary tract symptoms in patients with benign prostatic enlargement: a possible link to storage symptoms. Urology. 2014;84:1181-7.

3. Levi A, Deters M. Benign Prostatic Hyperplasia. New York: Nueva, Medscape; 2017. Available from: http://www.emedicine.medscape.com/article/437359-overview\#a4. [Last accessed on 2018 Sep 10]

4. Rył A, Rotter I, Miazgowski T, Słojewski M, Dołęgowska B, Lubkowska A et al. Metabolic syndrome and benign prostatic hyperplasia: association or coincidence? Diabetol Metab Syndr. 2015;7:94-101.

5. Parsons JK, Sarma AV, McVary K, Wei JT. Obesity and benign prostatic hyperplasia: clinical connections, emerging etiological paradigms and future directions. J Urol. 2013:189:S102-6.

6. Gacci M, Sebastianelli A, Salvi M, De Nunzio C, Tubaro A, Vignozzi L, et al. Central obesity is predictive of persistent storage LUTS after surgery for benign prostatic enlargement: results of a multicenter prospective study. BJU Int. 2015;116:271-7.
7. Antunes AA, Araújo LH, Nakano E, Muracca E, Srougi M. Obesity may influence the relationship between sex hormones and lower urinary tract symptoms. Int Braz J Urol. 2014;40:240-6.

8. Bhindi B, Margel D, Trottier G, Hamilton RJ, Kulkarni GS, Hersey KM, et al. Obesity is associated with larger prostate volume but not with worse urinary symptoms: analysis of a large multiethnic cohort. Urology. 2014;83:81-7.

9. Jung JH, Ahn SV, Song JM, Chang SJ, Kim KJ, Kwon SW, et al. Obesity as a risk factor for prostatic enlargement: a retrospective cohort study in Korea. Int Neurourol J. 2016;20:321-8.

10. Yin Z, Yang JR, Rao JM, Song W, Zhou KQ. Association between benign prostatic hyperplasia, body mass index, and metabolic syndrome in Chinese men. Asian J Androl. 2015;17:826-30.

11. Fowke JH, Koyama T, Fadare O, Clark PE. Does inflammation mediate the obesity and BPH relationship? An epidemiologic analysis of body composition and inflammatory markers in blood, urine, and prostate tissue, and the relationship with prostate enlargement and lower urinary tract symptoms. PLoS One. 2016;11:e0156918.

12. Romero-Martínez M, Shamah-Levy T, Cuevas-Nasu L, Humarán IM, Gaona-Pineda EB, Gómez-Acosta LM, et al. Diseño metodológico de la encuesta nacional de salud y nutrición de medio camino 2016. Salud Pública Méx. 2017;59:299-305.

13. Calogero AE, Burgio G, Condorelli RA, Cannarella R, La Vignera S. Epidemiology and risk factors of lower urinary tract symptoms/benign prostatic hyperplasia and erectile dysfunction. Aging Male. 2019;22:12-9.

14. Vignozzi L, Gacci M, Maggi M. Lower urinary tract symptoms, benign prostatic hyperplasia and metabolic syndrome. Nat Rev Urol. 2016;13:108-19.

15. Raheem OA, Parsons JK. Associations of obesity, physical activity and diet with benign prostatic hyperplasia and lower urinary tract symptoms. Curr Opin Urol. 2014;24:10-4. 